\title{
LEXICON
}

VOLUME $4 \quad$ Number 1, October $2015 \quad$ Page 114-122

\section{POLITENESS STRATEGIES IN THE BEL AMI MOVIE}

\author{
Zulfia Muftiarizqi
}

\begin{abstract}
This undergraduate thesis examines a movie entitled "Bel Ami". It focuses on the politeness strategies used in the dialogues that involve George as the main character. The objectives of this paper are to identify and classify the politeness strategies that appear and to find the most frequently performed politeness strategies by upper class characters in the movie. The analysis is based on the classification of politeness strategies by Brown and Levinson. The result of the analysis indicates that there are 61 speech acts that contain politeness strategies. The highest number of strategy that is found is positive politeness strategy comprising 28 strategies (45.90\%). It is likely because the speakers and hearers have close relationships as colleagues and the dialogues are dominated by common everyday conversations. The most frequently politeness strategies performed by upper class characters is Bald on record strategy 1 that is Cases of non-minimization of the face threat with $5(16.13 \%)$ strategies. It is possibly because as the hearer, George has less power than the speakers who belong to the upper class people.
\end{abstract}

Keyword: politeness, politeness strategies, Bel Ami, upper class

\section{Intisari}

Skripsi ini meneliti tentang sebuah film yang berjudul Bel Ami. Penelitian ini berfokus pada strategi kesopanan yang digunakan dalam dialog-dialog yang melibatkan George sebagai karakter utama dalam film. Tujuan dari penelitian ini adalah untuk mengidentifikasi dan mengkalsifikasi strategi kesopanan yang muncul dan untuk menemukan strategi kesopanan yang paling sering ditunjukkan oleh karakter yang berasal dari kalangan kelas atas di film. Penelitian ini menggunakan klasifikasi dari strategi kesopanan yang disusun oleh Brown dan Levinson. Hasil dari skripsi ini menemukan bahwa ada 61 tuturan yang mengandung strategi kesopanan. Strategi yang paling banyak ditemukan adalah strategi kesopanan positif dengan 28 strategi (45.90\%). Ini terjadi karena para penutur memiliki hubungan yang dekat sebagai rekan serta dialog-dialog tersebut didominasi oleh bahasa intim yang biasa digunakan sehari-hari. Strategi kesopanan yang paling sering digunakan oleh karakter kalangan kelas atas adalah strategi Bald on Record 1 yaitu Cases of non-minimization of the face threat dengan 5 strategi (16.13\%). Kemungkinan ini karena sebagai pendengar, George mempunyai wewenang yang lebih lemah daripada para penutur yang berrasal dari kalangan atas.

Kata Kunci: Kesopanan, strategi kesopanan, Bel Ami, karakter kelas atas 


\section{INTRODUCTION}

Politeness is studied in pragmatics focusing on issues such as manners and etiquette. According to Brown and Levinson stated in Nadar, everybody has "face" that they have to understand each other. Regarding to this, people need to respect one another's face. According to them, each individual has two types of face, positive and negative faces. The positive face is the individual's desire to be appreciated and approved in social interaction. Otherwise, the negative face is the desires for freedom of action and freedom from imposition. (32)

Although politeness is reflected in daily life, politeness is also considered in the making of a movie dialogue. For this research, the researcher took the politeness in Bel Ami, a movie adapted from 1885 novel from the same title, as the object of the research. The source of the data is the subtitle of the movie along with the contexts. The data are all dialogues that qualify as polite acts.

The setting of the film is in Paris highlightened the life of upper and middle-class societies. The story is about the life of a successful journalist, a middle class man, who manipulates the power, intelligent, and wealth of his mistress, an upper class woman. Since the characters in the movie are upper class people, the researcher aims to identify the politeness strategies performed by them. It is interesting that different social classes perform different politeness strategies.

As mentioned before, this movie is adapted from a French novel entitled Bel Ami or The History of a Scoundrel: A Novel. The author of the novel is Guy de Maupassant.

\section{METHOD}

The data source is the subtitle of the movie. The data collection is started by reading closely and the movie is watched at the same time. In order to see the accuracy of the subtitle the dialogues have to be listened carefully. Because this research is focused on the politeness strategies contained in dialogues that involve George, dialogues that contain politeness strategies are underlined. The dialogues that have been underlined are listed. They are provided with the time stamp and the context of the dialogue. From the movie, the researcher collects 61 dialogues that become the data.

The data are then classified into the politeness strategies according to Brown and Levinson stated in
Goody. Politeness strategy is divided into two type of strategy. They are on record and off record. On record is separated into two sub categories. They are politeness without redressive action or bald on-record and politeness with redressive action which includes positive politeness and negative politeness. There are two type of Bald on-record strategies (Cases of nonminimization of the face threat and Cases of FTAoriented bald-on-record usage). There arefifteen spesific types of positive politeness (Notice, attend to hearer; Exaggerate; Intensify interest to hearer; Use in-group identity markers; Seek agreement; Avoid disagreement; Presuppose/raise/assert common ground; Joke; Assert or presuppose speaker's knowledge of concern for hearer's wants; Offer, promise; Be optimistic; Include both speaker and hearer in the activity; Give or ask for reasons; Assume or assert reciprocity; Give gift to $\mathrm{H})$. There are ten substrategies address to the hearer's negative face (Be conventionally Indirect; Question, hedge; Be pessimistic; Minimize the imposition; Give deference; Apologize; Impersonalize speaker and hearer; State the FTA as a general rule; Nominalize; Go on record as incuring a debt, or as not indebting hearer). The last politeness strategy is off record. There are 15 types of off record politeness strategy (Give hints; Give association clues; Presuppose; Understate; Overstate; Use tautologies; Use contradictions; Be ironic; Use metaphors; Use rhetorical questions; $\mathrm{Be}$ ambiguous; $\mathrm{Be}$ vague; Over- generalize; Displace hearer; Be incomplete).

After classifying the collected data, the present researcher describes the most performed politeness strategies in the movie. In relation to the second objective, the analysis is more focused on politeness strategies performed by the upper class people in the movie. The data are then selected based on the speakers who are upper class people. The results of the analysis are presented in a table of percentage.

\section{PREVIOUS RESEARCHES}

Several researches on politeness have been done. Iqbal (2013) examined the politeness strategies in making requests performed by English Department students in the Faculty of Cultural Sciences, Universitas Gadjah Mada. The objectives of his research are to identify the performed politeness strategies in making request and to discover whether the politeness strategies are affected by social status of the hearers. The result of his research is the respondents performed the negative politeness strategies in making request. 
Another result is the performed politeness strategies are also affected by social status of the hearers.

Charismawati (2014) investigated refusals in three American drama movies. She identified and classified the positive and negative politeness strategies in the movies. The title of the research is Positive and Negative Politeness of Refusals in Three American Drama Movies. From 73 refusals, she found 32 (43.8\%) positive politeness strategies and 41 (56.2\%) negative politeness strategies. The most frequently used is positive politeness strategy 13 (give or ask for reason) with 7 (21.8\%) strategies.

Sofiehara (2014) investigated negative politeness strategies of requests in The Last Song movie. The result is that there are 37 requests in negative politeness strategies identified in the movie. The most commonly used negative politeness strategy is strategy 2 (question, hedge) with 12 strategies.

This present research is different with the researches above. The data in this research are from a movie. Meanwhile, Iqbal analyzed data from real conversation. Charismawati and Sofiehara also analyzed data from movies, but the chosen movies are different from the chosen movie in this research.

\section{FINDING AND DISCUSSION}

This section presents and discusses the findings of politeness strategies that appeared in the movie Bel Ami. This chapter is divided into two parts. The first part discusses the classification of politeness strategies found in the movie and the frequency of the uses. The second part discusses about the politeness strategies used by the upper class characters in the movie. The analysis in this chapter is discussed by presenting the data with the analysis. The data which contain politeness strategies are sorted based on the speakers who belong to upper class level of society. It is provided with the analysis of the data also.

\section{Politeness Strategy in the Dialogues that Involve George}

From the data source, there are 61 politeness strategies found. In this section, the speech acts that contain politeness strategies are classified according to politeness strategies proposed by Brown and Levinson: Bald on Record, Positive Politeness, Negative Politeness and Off Record. Table 1 shows the distribution of politeness strategies found in the data.

\section{Table 1 Politeness Strategies Found in the Data}

\begin{tabular}{|c|c|c|}
\hline Strategies & $\begin{array}{l}\text { Number of } \\
\text { strategies } \\
\text { (in total) }\end{array}$ & $\begin{array}{l}\text { Percentage } \\
\quad(\%)\end{array}$ \\
\hline \multicolumn{2}{|c|}{$\begin{array}{l}\text { 1. On record (bald on-record, positive politeness, } \\
\text { and negative politeness }\end{array}$} & \\
\hline \multicolumn{2}{|c|}{ 1.a. Without redressive action (Bald on-record) } & \\
\hline $\begin{array}{l}\text { Cases of non-minimization of the } \\
\text { face threat }\end{array}$ & 5 & $8.20 \%$ \\
\hline $\begin{array}{l}\text { Cases of FTA-oriented bald-on- } \\
\text { record usage }\end{array}$ & 3 & $4.92 \%$ \\
\hline Total & 8 & $13.11 \%$ \\
\hline \multicolumn{3}{|c|}{$\begin{array}{l}\text { 1.b. With redressive action (positive politeness and negative } \\
\text { politeness) }\end{array}$} \\
\hline \multicolumn{3}{|l|}{ 1.b.1. Positive politeness } \\
\hline Strategy 1 : Notice, attend to hearer & 2 & $3.28 \%$ \\
\hline \multicolumn{3}{|l|}{ Strateg } \\
\hline y 2 : Exaggerate & 1 & $1.64 \%$ \\
\hline Strategy 5 : Seek agreement & 6 & $9.84 \%$ \\
\hline Strategy $6:$ Avoid disagreement & 3 & $4.92 \%$ \\
\hline $\begin{array}{l}\text { Strategy } 7: \text { Presuppose/raise/ } \\
\text { assert common ground }\end{array}$ & 5 & $8.20 \%$ \\
\hline $\begin{array}{l}\text { Strategy } 9: \text { Assert or presuppose } \\
\text { speaker's knowledge of concern for } \\
\text { hearer's wants }\end{array}$ & 1 & $1.64 \%$ \\
\hline Strategy $10:$ Offer, promise & 1 & $1.64 \%$ \\
\hline Strategy $11:$ Be optimistic & 4 & $6.56 \%$ \\
\hline $\begin{array}{l}\text { Strategy } 12: \text { Include both speaker } \\
\text { and hearer in the activity }\end{array}$ & 2 & $3.28 \%$ \\
\hline $\begin{array}{l}\text { Strategy } 13 \text { : Give (or ask for) } \\
\text { reasons }\end{array}$ & 3 & $4.92 \%$ \\
\hline Total & 28 & $45.90 \%$ \\
\hline \multicolumn{3}{|l|}{ 1.b.2. Negative politeness } \\
\hline Strategy 2: Question, hedge & 2 & $3.28 \%$ \\
\hline Strategy $3:$ Be pesimistic & 1 & $1.64 \%$ \\
\hline Strategy 5 : Give deference & 2 & $3.28 \%$ \\
\hline Strategy $6:$ Apologize & 3 & $4.92 \%$ \\
\hline $\begin{array}{l}\text { Strategy } 8: \text { State the FTA as a } \\
\text { general rule }\end{array}$ & 1 & $1.64 \%$ \\
\hline Total & 9 & $14.75 \%$ \\
\hline \multicolumn{3}{|l|}{ 2. Off record } \\
\hline Strategy $1:$ Give hints & 7 & $11.48 \%$ \\
\hline Strategy 2 : Give association clues & 3 & $4.92 \%$ \\
\hline Strategy 3 : Presuppose & 2 & $3.28 \%$ \\
\hline Strategy 4 : Understate & 1 & $1.64 \%$ \\
\hline Strategy $6:$ Use tautologies & 1 & $1.64 \%$ \\
\hline Strategy 7 : Use contradictions & 1 & $1.64 \%$ \\
\hline Strategy 13 : Over- generalize & 1 & $1.64 \%$ \\
\hline Total & 16 & $26.23 \%$ \\
\hline Grand Total & 61 & $100.00 \%$ \\
\hline
\end{tabular}

From that result, it is found that the most frequent 
strategy used in the dialogue that involves George is positive politeness strategy with $28(45.90 \%)$ utterances. The specific strategy that is the most used is Seek agreement (strategy 5) with 6 (9.84\%) utterances and in the second place is Presuppose/raise/assert common ground (strategy 7 ) with 5 (8.20\%) utterances. The second place is off record strategy with 16 (26.23\%) utterances. The most is Give hints (strategy 1) with 7 (11.48\%) utterances. For further explanation about the analysis is discussed below.

\section{Positive Politeness}

\section{Strategy 5 (Seek agreement)}

\section{[1] 00:08:50.280 $\rightarrow$ 00:08:59.129}

In the dining room all of the guest are chatting each other. Madeleine asks George that whether he was in Algeria or not. The other dinner guests notice them. It seems like they want to know more about George Duroy. So, Madeleine starts to give some question to George. George tells about himself. He tells about his meeting with Charles before but he asks for agreement about it to Charles.

\section{Madeleine : You were in Algeria? George : Yes.}

Charles and I were first there together, five... Five years ago?

Charles : Five years.

Example [1] can be classified as one example of positive politeness strategy 5 because it contains question that the answer is repeating part of it, rather than answers by yes or no. The answer is repeating the question part "five years". The example 7 is said by George that means he is seeking for agreement form Charles about their first meeting. It means that George wants to make the hearer to trust his utterance. He convinces the people by asking Charles.

\section{$[2]$ 00:09:09.007 $\rightarrow$ 00:09:25.281}

At the dinner time George Duroy tells about his location at the last war in edge of Sahara. Hearing about that Virginie is curious about the myth in Sahara. Then she asks about it to George. She wants George to tell the story.
Virginie : I once heard a very foolish story about the desert. It may well be a myth, but I find it rather romantic.

\section{I was told that the sands sing?} $\mathrm{Hmm}$ ?

George : Oh, it's true. It's an effect of the wind on the dunes. It makes a kind of music

Speech act [2] contains positive politeness strategy 5 because it shows the speaker does the "safe topics". The speaker (Virginie) stresses her agreement with hearer (George). Virginie intends to rise as a way of doing FTA of initiating a conversation with George who is still a stranger for her. It shows how Virginie has an interest in maintaining a relationship with George.

\section{Strategy 7 (Presuppose/raise/assert common ground)}

[3] 00:09:25.982 $\rightarrow$ 00:09:49.723

In the dinner party the guests are curious about George. They ask many question about his condition when he was in the war. Madeleine asks where George stays when he was in the war. It is in Sahara. Then Virginie asks something about the myth there. George explains it based on his feeling about the myth. Clotilde seems disbelieve about George feeling but Clotilde is disagree about what George says.

Virginie : Oh. And what does it sound like?

George : It sounds very sad and mournful. At least, it does to a lonely soldier.

Clotilde : You? But how could you be lonely? And there, where the women are divine

George : The women are ravishing, and yet I was still homesick.

Example [3] can be regarded as an example of positive politeness strategy 7 because it shows personalcenter switch. It describes how the speaker considers that the hearer has same knowledge with the speaker. That utterance shows how Clotilde does not believe that George feels so lonely in Sahara. She thinks that they have same known that woman are divine there. It shows how Clotilde knows about Sahara condition same as George who has lived there. 
$[4]$ 00:25:57.723 $\rightarrow$ 00:26:17.167

Clotilde and George go to the night club. Accidentally they meet a prostitute worker who knows George. She comes to them and says hi to George. She tries to seduce George again but George acts like he does not know her. She criticizes George's attitude which reject her.

$\begin{array}{ll}\text { A Prostitute Worker } & : \text { Hello. } \\ \text { Clotilde } & : \text { Hello. } \\ \text { A Prostitute Worker } & : \text { I was talking to your friend } \\ & \text { here. } \\ \text { Clotilde } & : \text { Georges? } \\ \text { George } & : \text { I think you've mistaken me } \\ & \text { for somebody else. } \\ \text { A prostitute Worker } & : \begin{array}{l}\text { So, I see. Not so friendly } \\ \text { after all, are we? }\end{array}\end{array}$

Example [4] can be included into positive politeness strategy 7 because it shows personal center switch between the speaker and hearer. In this utterance it seems that the speaker and hearer have same knowledge. Besides that the speaker merges the "I" the "you" into inclusive "we". It happens because the prostitute worker as the speaker uses "we" to George who is the hearer and the context itself both of them have ever met before.

\section{Off Record}

\section{Strategy 1 (Give hints) \\ [5] 00:13:04.117 $\rightarrow$ 00:13:11.712}

In Madeleine house George is helped by Madeleine to write his first journal. She gives all off her ideas in her mind. She dictates George to write her idea about making a letter as the journal. George feels so happy because it makes his work becomes easier. He says that he likes being a journalist in order to give Madeleine request to always help him to write articles.

$\begin{array}{ll}\text { George } & : \text { I like being a journalist. } \\ \text { Madeleine } & : \text { I hope you don't think I'm going to } \\ & \text { write all your articles for you. } \\ \text { George } & : \text { No. }\end{array}$

Example [5] can be included into off record strategy 1 because it shows how the speaker says something that is not explicitly relevant that makes hearer has to search for an interpretation of the possible relevance. This dialogue shows how George tries to deliver his message toward Madeleine. George tries to say that he wants Madeleine to always guide him for his career as journalist. He says "I like being journalist" in order to make Madeleine happy to guide him.

[6] 00:18:43.706 $\rightarrow$ 00:18:54.517

George Duroy makes a visit for Clotilde. In Clotilde's house he is welcome by Clotilde's daughter Laurine in the living room. They are getting closer even playing a game and Clotilde join in it. Suddenly a maid comes to pick Laurine up for lunch. Laurine feels sad to leave George, she asks them to let her be there but George promises her that they will meet again.

$$
\begin{aligned}
& \text { Maid } \quad \text { It is time for Laurine to take her lunch. } \\
& \text { Laurine } \quad: \text { I want to stay with Georges. } \\
& \text { George } \quad \text { : Well, perhaps you'll permit me to call } \\
& \text { Laurine } \quad \text { on you again. }
\end{aligned}
$$

Example [6] can be classified into off record politeness strategy 1 because it shows how the speaker says something that is not explicitly relevant that makes hearer has to search for an interpretation of the possible relevance. In this dialogue Laurine tries to say that she does not want to take her lunch and wants to stay with George to continue the game. She does not straightforwardly say that she does not want take her lunch. She just says that she wants to stay with George.

\section{Politeness Strategies Used by Upper Class Characters toward George as Middle Class Individual}

Based on the data source, in total there are 61 utterances contains politeness strategies found. In this section, the data which is used are the politeness strategies used by upper class characters. There are 31 utterances selected. This movie sets in 19th century in Paris. At that moment in Paris life, there are distinctions between rich and poor neighborhoods. There are three social classes in Paris. They are upper class dominated by aristocratic people (Nobility, royal families, reach people), middle class or called Bourgeoisie (the white collar occupations), and lower class (workers 
in extractive, manufacturing, and service industries). The lifestyle of the upper class is different from other class. They ride through the city streets in horse drawn carriages while everyone else walked. When city life becomes oppressive and unpleasant, upper class families take journeys into the countryside. (Gallery. sjsu) There are some characters that belong to upper class society: Charles Forestier, Madeleine Forestier, Virginie Rousset, Clotilde de Marelle, Monsieur Rousset, Comte de Vaudrec, Suzanne, and Laurine.

The speech acts that contain politeness strategies used by the upper class characters are classified according to politeness strategies proposed by Brown and Levinson theory. Table 2 shows the distribution of politeness strategies used by upper class characters found in the data.

Table 2 Politeness Strategies Used by Upper Class Characters

\begin{tabular}{|c|c|c|}
\hline Strategies & $\begin{array}{l}\text { Number of } \\
\text { strategies } \\
\text { (in total) }\end{array}$ & $\begin{array}{l}\text { Percentage } \\
(\%)\end{array}$ \\
\hline \multicolumn{2}{|c|}{$\begin{array}{l}\text { 1. On record (bald on-record, positive politeness, } \\
\text { and negative politeness }\end{array}$} & \\
\hline \multicolumn{2}{|c|}{ 1.a. Without redressive action (Bald on-record) } & \\
\hline $\begin{array}{l}\text { Cases of non-minimization of the } \\
\text { face threat }\end{array}$ & 5 & $16.13 \%$ \\
\hline $\begin{array}{l}\text { Cases of FTA-oriented bald-on- } \\
\text { record usage }\end{array}$ & 2 & $6.45 \%$ \\
\hline Total & 7 & $22.58 \%$ \\
\hline \multicolumn{3}{|c|}{$\begin{array}{l}\text { 1.b. With redressive action (positive politeness and negative } \\
\text { politeness) }\end{array}$} \\
\hline \multicolumn{3}{|l|}{ 1.b.1. Positive politeness } \\
\hline Strategy 1 : Notice, attend to hearer & 2 & $6.45 \%$ \\
\hline Strategy 2 : Exaggerate & 1 & $3.23 \%$ \\
\hline Strategy 5 : Seek agreement & 1 & $3.23 \%$ \\
\hline Strategy $6:$ Avoid disagreement & 2 & $6.45 \%$ \\
\hline $\begin{array}{l}\text { Strategy } 7: \text { Presuppose/raise/ } \\
\text { assert common ground }\end{array}$ & 3 & $9.68 \%$ \\
\hline $\begin{array}{l}\text { Strategy } 9 \text { : Assert or presuppose } \\
\text { speaker's knowledge of concern for } \\
\text { hearer's wants }\end{array}$ & 1 & $3.23 \%$ \\
\hline Strategy 10 : Offer, promise & 1 & $3.23 \%$ \\
\hline Strategy 11 : Be optimistic & 1 & $3.23 \%$ \\
\hline $\begin{array}{l}\text { Strategy } 12 \text { : Include both speaker } \\
\text { and hearer in the activity }\end{array}$ & 2 & $6.45 \%$ \\
\hline $\begin{array}{l}\text { Strategy } 13: \text { Give (or ask for) } \\
\text { reasons }\end{array}$ & 3 & $9.68 \%$ \\
\hline Total & 17 & $54.84 \%$ \\
\hline \multicolumn{3}{|l|}{ 1.b.2. Negative politeness } \\
\hline Strategy 2 : Question, hedge & 1 & $3.23 \%$ \\
\hline Strategy 6 : Apologize & 1 & $3.23 \%$ \\
\hline
\end{tabular}

\begin{tabular}{|l|c|c|}
\hline \multicolumn{1}{|c|}{ Strategies } & $\begin{array}{c}\text { Number of } \\
\text { strategies } \\
\text { (in total) }\end{array}$ & $\begin{array}{c}\text { Percentage } \\
(\%)\end{array}$ \\
\hline Total & 2 & $6.45 \%$ \\
\hline 2. Off record & 2 & $6.45 \%$ \\
\hline Strategy 1 : Give hints & 1 & $3.23 \%$ \\
\hline Strategy 3 : Presuppose & 1 & $3.23 \%$ \\
\hline Strategy 6 : Use tautologies & 1 & $3.23 \%$ \\
\hline Strategy 13 : Over- generalize & 5 & $16.13 \%$ \\
\hline Total & 31 & $100.00 \%$ \\
\hline Grand Total & & \\
\hline
\end{tabular}

From that result, it is found that the most frequent strategy used by upper class people in the dialogues that involve George is Bald on record strategy 1 that is Cases of non-minimization of the face threat with $5(16.13 \%)$ utterances. The second place are positive politeness strategy 7 that is Presuppose/raise/assert common ground and strategy 13 Give or ask for reason with 3 (9.68\%). Bellow is discussion about the analysis from the two types of politeness strategies that are frequently used by upper class people in Bel Ami movie:

\section{Bald on Record}

\section{Strategy 1 (Cases of non-minimization of the face threat)}

[7] 00:13:44.407 $\rightarrow$ 00:13:59.339

Madeleine helps George to write his first journal in her house. They talk each other then getting closer. George talks to Madeleine indirectly that he is attracted with Madeleine but Madeleine straightly refuse him. She wants to make a professional relationship with George. She emphasizes that she cannot become his mistress. She asks him to pay attention to her.

\section{Madeleine : Look at me, please.}

: I will never be your mistress. Do you understand?

George : Yes.

Madeleine : Good.

Example [7] can be classified as one of bald on record strategy, cases of non-minimization of the face threat because it provides metaphorical urgency for emphasis. It shows that speaker's speak is very important. It is uttered by Madeleine who wants to 
make a serious conversation with George about her refusal for George's feeling. The part "look at me" is used for emphasizing. It emphasizes the command that Madeleine utters to George and the command has to be done as soon as after that.

\section{$[8]$ 01:15:11.799 $\rightarrow$ 01:15:19.019}

Virgine sees George at the street. George is in a hurry. He does not want to meet Virginie. But Virginie forces him to go together and talk each other.

Virgine : You're meeting someone else.

Take me with you. I need to talk to you. Just for an hour.

George : Remember where you are!

Example [8] can be regarded as one example of on record strategy cases of non-minimization of the face threat because it shows how the speaker's utterance provides metaphorical urgency for emphasis. It communicates the urgency. It is said by Virginie who wanted to talk to George. The part "I need to talk to you. Just for an hour." gives description how Virginie has to talk with George. It is a very urgent matter so that the Virginie adds an emphasis at the last sentence.

\section{[9] 01:15:22.268 $\rightarrow$ 01:15:48.006}

Virgine sees George at the street. George is in a hurry. He does not want to meet Virginie. But Virginie forces him to go together and talk each other because she wants to be with George.

Virginie : You shouldn't have seduced me. You should have left me where I was, a happy and faithful wife.

Please, let me come with you. Please, just for an hour. I've got something so important to tell you. Something to your advantage. It's about my husband. Please.

Example [9] can be included into on record strategy cases of non-minimization of the face threat because it provides metaphorical urgency for emphasis. It shows in "I've got something so important to tell you". It communicates the urgency that is said by Virginie to George. It shows how Virginie wants to talk to George at that moment. She wants to give important information for George.

\section{Positive Politeness}

\section{Strategy 7 (Presuppose/raise/assert common ground)}

[10] 9:25.982 $\rightarrow$ 00:09:49.723

In the dinner party the guests are curious about George. They ask many question about his condition when he was in the war. Madeleine asks where George stays when he was in the war. It is in Sahara. Then Virginie asks something about the myth there. George explains it based on his feeling about the myth. Clotilde seems disbelieve about George feeling but Clotilde is disagree about what George says.

\section{Virginie : Oh. And what does it sound like? \\ George : It sounds very sad and mournful. At least, it does to a lonely soldier. \\ Clotilde : You? But how could you be lonely? And there, where the women are divine. \\ George : The women are ravishing, and yet I was still homesick.}

Example [10] can be regarded as an example of positive politeness strategy 7 because it shows personalcenter switch. It describes how the speaker considers that the hearer has same knowledge with the speaker. That utterance shows how Clotilde does not believe that George feels so lonely in Sahara. She thinks that they have same known that woman are divine there. It shows how Clotilde knows about Sahara condition same as George who had lived there.

\section{$[11]$ 00:33:44.773 $\rightarrow$ 00:34:01.798}

George is invited into a dinner party with the high social class people. He comes and meets Clotilde there. They have not met each other again for a short of time. Knowing George's cold face, Clotilde asks him to give her a smile. 
Virginie : Now, do you remember Madame de Marelle?

George : Of course

Clotilde : Well, Bel ami. Don't you have a smile for your old friend?

Pierre : Let's go into dinner, ladies.

Example [11] contains positive politeness strategy 7 because it is part of presuppose knowledge of hearer's wants and attitude. The negative question above is used as a way to indicate that the speaker (Clotilde) knows hearer's (George) wants. This utterance shows how Clotilde knows that George is reluctant to say hello to her because she mad at him before. She tries to make the atmosphere between she and George become better.

\section{Strategy 13 (Give or ask for reasons)}

\section{[12] 00:05:32.207 $\rightarrow$ 00:05:46.229}

At a bar George Duroy meets Charles Foristier by accident. They have a talk in the middle of the crowd with having some drinks. They talk about job in journalistic then Charles invites George to have dinner in his house in order to help George to get a connection for his job.

Charles : Why don't you come to dinner tomorrow night? Come and meet my wife.

George : Well, the thing is, uh, I don't have any evening clothes.

Charles : Well, here.

Example [12] can be classified in positive politeness strategy 13 because it uses "why don't" that describes that the speaker asks for reason. By using "why don't" the speaker (Charles) assumes that there is not a good reason for hearer (George) to refuse to cooperate. It is kind of optimism done by the speaker. This utterance shows that Charles invited George to his house and there is no reason for George to refuse his invitation.

\section{[13] 00:28:08.312 $\rightarrow$ 00:28:28.837}

In the La Vie Francaise office, George comes to get his salary. He only get a little, it is because his article is not so interesting. Charles meets him to show his anger.
He suggests George to do his job which is making good articles.

\section{Charles : Why don't you try earning it?}

Diary Of A Cavalry Officer. Whatever happened to that?

Perhaps you can get my wife to write it. Perhaps you think you can draw your salary and she will do your job for you.

Now, I...

I brought you into my home, I fed you, I clothed you, and how do you repay me?

Example [13] can be included into positive politeness strategy 13 because it uses "why don't" that describes that the speaker asks for reason. By using "why not" the speaker (Charles) assumes that the hearer (George) has no reason to deny that he cannot cooperate. This utterance shows that Charles wants George to do his job well because he does not write a good article for several times. It shows that there is no reason to George for wasting time with his bad article.

\section{CONCLUSION}

From the analysis that has been discussed in the previous chapter there are 61utterances contain politeness strategies found. There are 8 (13.11\%) utterances in bald on record strategies, 28 (45.90\%) in positive politeness strategies, $9(14.75 \%)$ in negative politeness strategies, and $16(26.23 \%)$ in off record strategies. These result shows that the speakers tend to use positive politeness strategies. It shows that the speakers don't care about the addressee's feelings or wants. It also happens because the speakers and hearers have close relationships as colleagues, they use positive politeness strategies that redress from normal everyday intimate language. As we can see the dialogues are dominated by conversation between George and his mistresses.

For the second aim of this research, the present researcher found that the most frequently performed politeness strategies by upper middle class people in the dialogues that involve George is Bald on record strategy 1 that is Cases of non-minimization of the face threat with $5(16.13 \%)$ utterances. It is possibly because as the hearer, George has less power than the speakers who belong to the upper class people. The speakers are powerful and do not care about maintaining face. 
The focus of this research gives limitations to it. Since only the dialogues involving George were investigated, the result of this study does not reflect the use of all politeness strategies performed in the movie. In addition, because the author only used one data source, the result of this study cannot be used to make generalizations for other movies of the same genre. Further research on the same topic might need to involve more than one data source to be able to make such a generalization.

\section{BIBLIOGRAPHY}

Bel Ami. Dirs. Declan Donnellan and Nick Omerod. Perf. Robert Pattinson, et al. Red Wave, 2012. Film.

Charismawati, Arie. "Positive and Negative Politeness of Refusals in Three American Drama Movies". Undergraduate Thesis. Universitas Gadjah Mada, 2014. Unpublished.

Cintas, Jorge Diaz, Pilar Orero and Aline Remael. Media for All: Subtitling for the Deaf, Audio Description, and Sign Language. Amsterdam: Rodopi, 2007. Print.

Cutting, Joan. Pragmatic an Discourse: A Resource Book for Students. London: Routledge, 2002. Print.

Goody, Esther N. Questions and Politeness. Cambridge: Cambridge University Press, 1987. Print.

Horn, Laurence R. and Gregory Ward, The Handbook of Pragmatics. Oxford: Blackwell, 2006. Print.
Iqbal, Ali. "Politeness Strategies in Requesting: A Case Study of English Department Student of FIB UGM". Undergraduate Thesis. Universitas Gadjah Mada, 2013. Unpublished.

Nadar, FX. Pragmatik dan Penelitian Pragmatik. Yogyakarta: Graha Ilmu, 2008. Print.

Sofiehara, Inorda. "Negative Politeness Strategies of Request in the Movie The Last Song". Undergraduate Thesis. Universitas Gadjah Mada, 2014. Unpublished.

Yule, George. Pragmatics. Oxford: Oxford University Press, 1996. Print.

\section{Internet sources:}

“Bel Ami” Wikipedia. 21 July 2015. Web. 6 July 2015. $<$ https://en.wikipedia.org/wiki/Bel_Ami>

"Social Classes Paris in the Nineteenth Century". Gallery.sjsu. n.d. Web. 19 March 2015. <http:// gallery.sjsu.edu/paris/social_classes/upper/ upper_more.html>

Ivandrofly. "Bel-Ami". subscene. n.d. srt. 25 March 2014. <http://subscene.com/subtitles/bel-ami/ english/606339>.

Russell, Tony, Allen Brizee, and Elizabeth Angeli. "MLA Formatting and Style Guide." The Purdue OWL. Purdue U Writing Lab, 4 Apr. 2010. Web. 19 Dec 2014. < https://owl.english.purdue.edu/ owl/resource/747/01/> 